\author{
Zh. Sarsenova \\ Master of Technical Sciences, Senior lecturer of ICT Educational Program \\ zhibek.sarsenova@astanait.edu.kz,orcid.org/0000-0002-7780-8070 \\ Astana IT University, Kazakhstan
}

Sh. Saimassayeva

Master of Technical Sciences, Senior lecturer of ICT Educational Program sholpan.saimassayeva@astanait.edu.kz,orcid.org/0000-0003-4482-8320 Astana IT University, Kazakhstan

A. Smaiyl

Master of Technical Sciences, Senior lecturer of ICT Educational Program assel.smaiyl@astanait.edu.kz, orcid.org/0000-0002-6215-932X Astana IT University, Kazakhstan

\title{
DETERMINATION OF THE MOST POLLUTED ATMOSPHERIC AIR POLLUTION CATEGORY OF ALMATY CITY
}

\begin{abstract}
This article discusses the impact of suspended particles on human health, by providing small definitions of PM2.5, including how they appear, what particles they consist of, and how they harm the respiratory and circulatory systems. In addition, the analysis of the pollution level of the city of Almaty for the last three years from March 22, 2017, to October 6,2020 , with categorical intermediate values of suspended particles was carried out. Careful work was done with the SCV file such as data was skipped in the cells, that is, there were empty values; translation to a single data type; filling in empty cells. It also considers making a decision on the six categories provided to identify the average meeting categories.

The authors identified specific categories based on digital readings of values received from sensors, where each category has its own verbal values that are understandable for each person. The indicator displays with weights as a graph for a specific Seifullin-Dulatov sensor location with categorical and without categorical division. Then for each intersection or location of the sensors is shown in a table. It is also revealed which level or category is the rarest among the others and the most common category as well.
\end{abstract}

Keywords: air pollution, environmental monitoring, data analysis.

\section{Introduction}

Atmospheric air is one of the vital components of the environment. It performs many functions, such as biological, transport, and production. Therefore, air pollution is one of the significant health risks associated with the environment.

Problems of atmospheric protection are a vast area of research. They include not only General problems of chemical technology, mechanical engineering, and meteorology but also issues that can be addressed by narrow specialists, such as mathematicians, physicists, programmers, analysts, etc. Atmospheric pollution factors may be related to natural processes and human activities. All sources of pollution are divided into natural and artificial. Biological pollutants are those of mineral and plant origin that enter the atmosphere because of volcanic eruptions and forest fires. In addition, natural air pollutants are dust, plant pollen, and so on. Artificial factors of air pollution are divided into transport, industrial, and household. 
In Kazakhstan, the primary sources of air pollution are large industrial enterprises, heating systems, and vehicles [1]. According to the Ministry of ecology, geology, and natural resources, since 2017, there has been a tendency to increase the emissions claimed by nature users by 52 thousand tons, or $1.2 \%$. At the same time, over the past five years, there has been a tendency to reduce them by 156 thousand tons or $2.2 \%$. That is, if in 2015 , the limit was 4.4 million tons of emissions; in 2019 it is already 4.3 million tons [2].

In this article [3], an info logical model is constructed that reflects the real world in a human-friendly concept, completely independent of the parameters of the semantic data model storage environment. This model solves the current problems of monitoring industrial emissions that affect air pollution. Taking into account all the factors discussed in this article and in the articles proposed by professors working in this direction, a data analysis has been carried out by us.

\section{Ecological factors}

Seven million people worldwide die from the effects of air pollution every year. Air pollution is the cause of respiratory, infectious, and heart diseases, stroke, lung cancer, and many others. Children who inhale dirty air are increasingly suffering from asthma, chronic lung failure, growth retardation, diabetes, childhood obesity, and mental retardation.

Like many other countries, Kazakhstan is firmly established in the list of countries with extremely negative environmental trends. Many residents of our country suffer from diseases of the upper respiratory tract and cancer. Furthermore, because of air pollution in Kazakhstan, the function of blood vessels in the lungs worsens, and the body's immune system is disrupted. Pollution in Kazakhstan occurs through the release of lead, benzapyrene, and formaldehyde into the air. The main source of air pollution is transport, which accounts for $70 \%$ of the total emission of harmful substances into the air basin. Moreover, it becomes more and more every year.

Therefore, according to Kazhydromet data, there are traces of active chemical compounds of hazard class 3, 4 (nitrogen oxide, carbon, sulfur) in the air, less often compounds of hazard class 1-2 [4].

The article mentions a lot about PM2.5, which is an air pollutant, that includes both solid micro particles and the smallest droplets of liquids. Both are approximately $10 \mathrm{~nm}$ to 2.5 microns in size. Other designations and names of PM2.5 particles: FSP (fine suspended particles), fine particles, fine particulate matter, fine suspended particles, fine dust.

All these particles and droplets smaller than 2.5 microns are suspended in the air. They are found both in the forest and on the sea, but it is in the city that they pose the greatest danger. First, there are usually a lot more of them in the city, and secondly, the chemical composition of fine aerosol in the city is more dangerous than in nature. It might be also noted, the composition of the PM2.5 aerosol and the parameters of individual particles may differ greatly in different cities [5].

\section{Data Analysis}

In the CSV file, data with 41 columns and 1291 entries and data starts from March 22, 2017, to October 6, 2020. The sensor is located in the location below at the intersection of Almaty streets. We use a Google Collaboratory to analyze this data. The Google Colaboratory is a free cloud service based on the Jupyter laptop that provides everything you need for machine learning right in the browser [6]. Fig. 1 shows the location of sensors and the default data type in the file. 


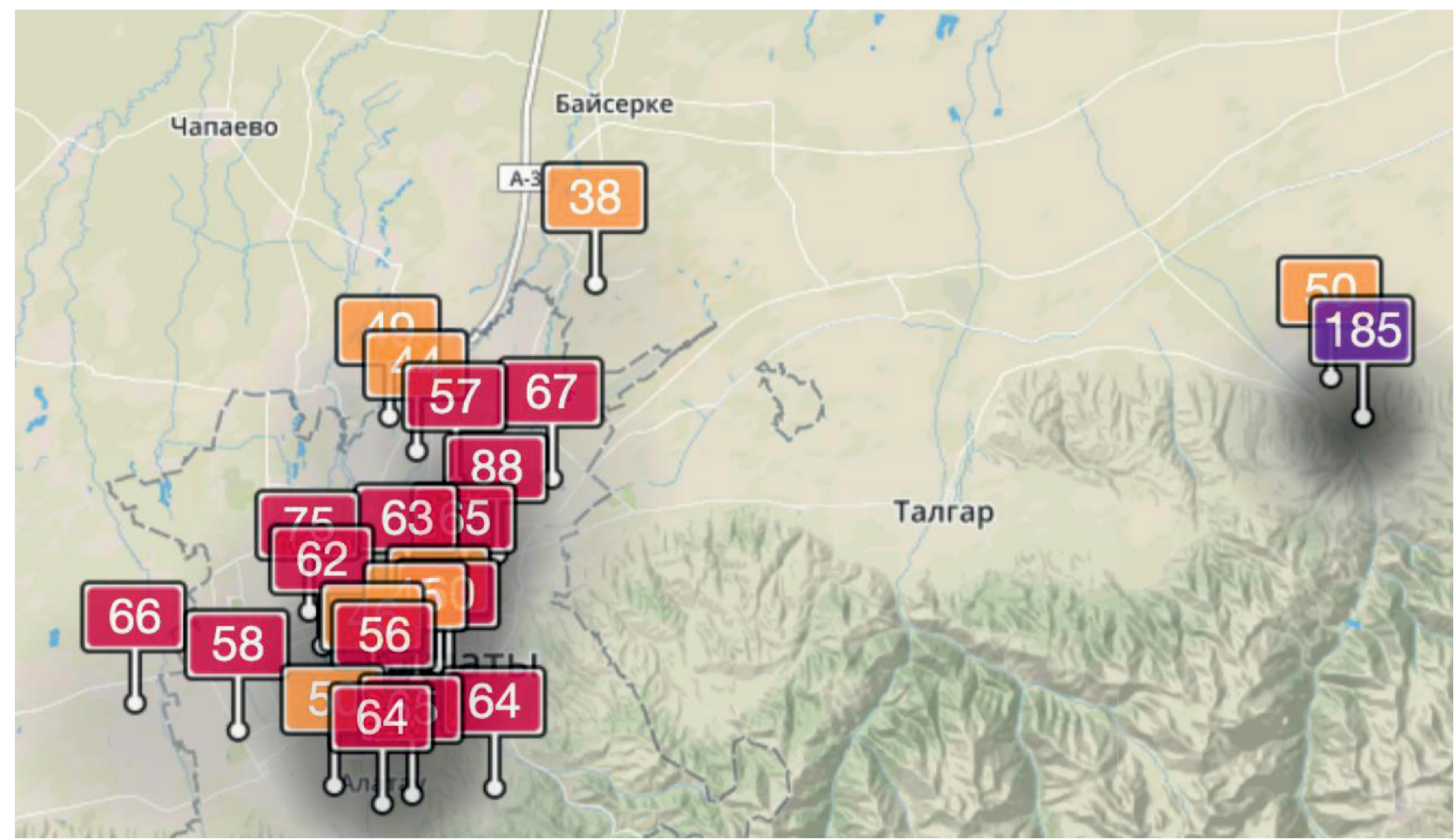

Fig.1. Locations of sensors on the map

As shown in Fig.1 above, the location of the sensors on the map is shown. In addition, the data type of each site is different and it is decided to change the data type to float type then convert it to one data type float. In our case, the last data Mukhanova_159 has an int data type. There are so many missing values. It means in those days sensors did not provide data, because of did not install sensors in that place. Table 1 shows the total count of missing values in each intersection of the street.

Table 1. Missing values

\begin{tabular}{|l|c|c|c|}
\hline \multicolumn{1}{|c|}{ name } & lat & lng & missing value \\
\hline Seifullin-Dulatov & 43.313 & 76.939 & 350 \\
\hline Al-Farabi-Markov & 43.224 & 76.938 & 110 \\
\hline Abay-Tilendiyev & 43.24 & 76.874 & 449 \\
\hline Gorky park & 43.265 & 76.973 & 646 \\
\hline Tolebi-Baizakov & 43.253 & 76.91 & 101 \\
\hline Rozybakiev- Baykadamov & 43.214 & 76.893 & 72 \\
\hline microdistr. Kok Kainar & 43.296 & 76.844 & 339 \\
\hline Ryskulov-Momyshuly & 43.254 & 76.82 & 472 \\
\hline Ermensay & 43.174 & 76.917 & 116 \\
\hline Tulebayev-Dzhambul & 43.248 & 76.949 & 325 \\
\hline Residential complex Solnechnaya Dolina & 43.189 & 76.868 & 263 \\
\hline Kamenskoe plateau & 43.177 & 76.966 & 122 \\
\hline Furmanov-Tashkent & 43.269 & 76.944 & 347 \\
\hline microdistrict Mamyr & 43.216 & 76.848 & 465 \\
\hline Residential complex-ASYL Arman & 43.231 & 76.754 & 1275 \\
\hline Residential complex- Zhana Kuat & 43.397 & 77.027 & 244 \\
\hline Baganashyl & 43.195 & 76.915 & 1134 \\
\hline
\end{tabular}




\begin{tabular}{|l|c|c|c|}
\hline \multicolumn{1}{|c|}{ name } & lat & lng & missing value \\
\hline Kurgauldy & 43.172 & 76.736 & 370 \\
\hline Voenniy gorodok & 43.369 & 76.987 & 1022 \\
\hline Microdistr. Karasu & 43.337 & 76.904 & 761 \\
\hline Satpayev-Lugansky & 43.354 & 77.457 & 496 \\
\hline Raiymbek Rural District Karasay district & 43.356 & 77.467 & 747 \\
\hline Shanyrak 2 & 43.177 & 76.943 & 1264 \\
\hline Energostroitel & 43.241 & 76.96 & 583 \\
\hline Zhana Kairat & 43.214 & 76.75 & 959 \\
\hline Almagul Microdistrict 24 & 43.297 & 76.852 & 1165 \\
\hline Akan Seri & 43.299 & 76.792 & 1238 \\
\hline micr.Mamyr & 43.312 & 77.001 & 1277 \\
\hline Miras 122 & 43.206 & 76.9 & 1124 \\
\hline Kurchatov 1 & 43.31 & 76.943 & 1289 \\
\hline Tatibekov & 43.213 & 76.846 & 1052 \\
\hline KazGU Parking & 43.1855 & 76.8716 & 1266 \\
\hline Kamyshinskaya & 43.254 & 76.855 & 1172 \\
\hline Tulebaeva 82 & 43.2795 & 76.9677 & 1289 \\
\hline Asanbai Askarov 60 & 43.223 & 76.919 & 1131 \\
\hline 3rd Ainabulak Microdistrict 107 & 43.3526 & 76.9993 & 1275 \\
\hline 5th Tau Samal line & 43.2576 & 76.9484 & 1280 \\
\hline Sagadat Nurmagambetov 330 & 49.628 & 72.986 & 1023 \\
\hline Timiryazev 17 & 49.628 & 73.046 & 1125 \\
\hline Microdistrict Karasu 2 & 43.178 & 76.87 & 1176 \\
\hline Mukanova 159 & 43.324 & 76.919 & 1291 \\
\hline
\end{tabular}

After the defining count of missing values in each location to avoid, empty values and analysis show us precise values, replacing, all empty values with mean values will be a good decision.

All air pollution values are divided into 6 categories, the lower the level of air pollution in the air; the better it is for us. The Table 2 below shows the levels of PM 2.5 values.

Table 2. Levels of PM 2.5

\begin{tabular}{|l|l|}
\hline Name of levels & Range of values PM $\mathbf{2 . 5}$ \\
\hline Low & $0-12$ \\
\hline Elevated & $13-34$ \\
\hline High & $35-55$ \\
\hline Very high & $56-149$ \\
\hline Dangerous & $150-249$ \\
\hline Poisonous & $250-$ max value \\
\hline
\end{tabular}

These diagrams (Fig.3, Fig.4) show frequently occurring values of the PM 2.5 air pollution level from a sensor that is located in the Seifullin-Dulatov location. 


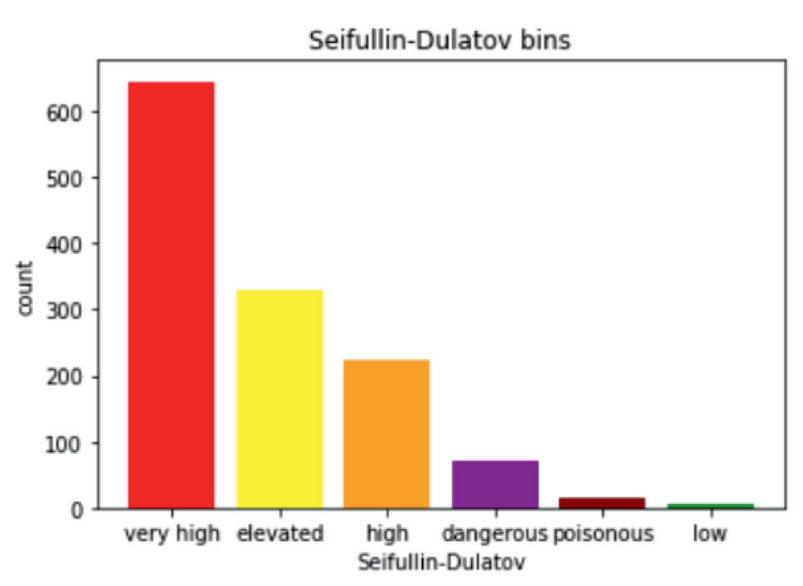

Fig. 3 The most frequent values in Seifullin-Dulatov street with category

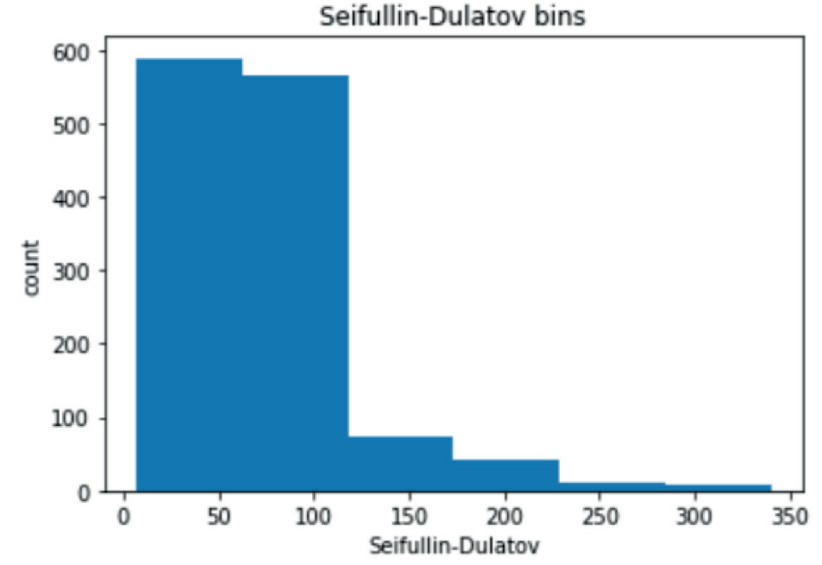

Fig. 4 The most frequent values in Seifullin-Dulatov streen without category

Table 3 shows the most frequent data values as a table in each locations.

Table 3. The most frequent values in each location

\begin{tabular}{|l|c|c|c|c|c|c|}
\hline \multicolumn{1}{|c|}{ Location of sensors } & Low & Elevated & High & Very high & Dangerous & Poisonous \\
\hline Seifullin-Dulatov & 16 & 330 & 223 & 5 & 645 & 72 \\
\hline Al-Farabi-Markov & 3 & 599 & 336 & 54 & 269 & 30 \\
\hline Abay-Tilendiyev & 6 & 350 & 593 & 96 & 212 & 34 \\
\hline Gorky park & 2 & 286 & 752 & 65 & 157 & 29 \\
\hline Tolebi-Baizakov & 13 & 526 & 262 & 200 & 250 & 40 \\
\hline Rozybakiev- Baykadamov & 4 & 523 & 260 & 245 & 238 & 21 \\
\hline microdistr. Kok Kainar & 21 & 258 & 199 & 20 & 699 & 94 \\
\hline Ryskulov-Momyshuly & 7 & 253 & 865 & 25 & 122 & 19 \\
\hline Ermensay & 0 & 617 & 194 & 285 & 192 & 3 \\
\hline Tulebayev-Dzhambul & 11 & 128 & 55 & 11 & 1059 & 27 \\
\hline $\begin{array}{l}\text { Residential complex Solnechnaya } \\
\text { Dolina }\end{array}$ & 0 & 98 & 1059 & 77 & 47 & 10 \\
\hline Kamenskoe plateau & 0 & 792 & 188 & 245 & 65 & 1 \\
\hline Furmanov-Tashkent & 4 & 192 & 999 & 18 & 71 & 7 \\
\hline microdistrict Mamyr & 7 & 350 & 596 & 90 & 214 & 34 \\
\hline Residential complex-ASYL Arman & 0 & 0 & 6 & 3 & 1280 & 2 \\
\hline Residential complex-Zhana Kuat & 23 & 427 & 131 & 93 & 548 & 69 \\
\hline Baganashyl & 0 & 1201 & 17 & 46 & 26 & 1 \\
\hline Kurgauldy & 0 & 389 & 497 & 222 & 170 & 13 \\
\hline Voenniy gorodok & 2 & 135 & 61 & 2 & 1076 & 15 \\
\hline Microdistr. Karasu & 10 & 165 & 95 & 12 & 966 & 43 \\
\hline Satpayev-Lugansky & 1 & 295 & 600 & 216 & 167 & 12 \\
\hline Raiymbek Rural District Karasay \\
district & 4 & 285 & 800 & 53 & 130 & 19 \\
\hline Shanyrak 2 & 0 & 11 & 1278 & 1 & 1 & 0 \\
\hline Energostroitel & 2 & 88 & 1196 & 1 & 4 & 0 \\
\hline Zhana Kairat & & & & & & 741 \\
\hline Almagul Microdistrict 24 & 119 & 1020 & 68 & 79 & 5 \\
\hline & 0 & 94 & 105 & \\
\hline
\end{tabular}




\begin{tabular}{|l|c|c|c|c|c|c|}
\hline \multicolumn{1}{|c|}{ Location of sensors } & Low & Elevated & High & Very high & Dangerous & Poisonous \\
\hline Akan Seri & 0 & 1268 & 3 & 19 & 1 & 0 \\
\hline micr.Mamyr & 0 & 1279 & 5 & 5 & 2 & 0 \\
\hline Miras 122 & 0 & 1258 & 19 & 12 & 2 & 0 \\
\hline Kurchatov 1 & 0 & & 1289 & 1 & 1 & 0 \\
\hline Tatibekov & 0 & 86 & 1100 & 53 & 51 & 1 \\
\hline KazGU Parking & 0 & 1288 & 1 & 2 & 0 & 0 \\
\hline Kamyshinskaya & 0 & 1225 & 2 & 63 & 0 & 0 \\
\hline Tulebaeva 82 & 0 & 1290 & 0 & 1 & 0 & 0 \\
\hline Asanbai Askarov 60 & 0 & 1267 & 10 & 12 & 2 & 0 \\
\hline 3rd Ainabulak Microdistrict 107 & 0 & 1290 & 1 & 0 & 0 & 0 \\
\hline 5th Tau Samal line & 0 & 1291 & 0 & 0 & 0 & 0 \\
\hline Sagadat Nurmagambetov 330 & 0 & 1104 & 28 & 122 & 35 & 2 \\
\hline Timiryazev 17 & 0 & 1249 & 25 & 6 & 11 & 0 \\
\hline Microdistrict Karasu 2 & 0 & 1266 & 1 & 24 & 0 & 0 \\
\hline Mukanova 159 & 1 & 650 & 194 & 72 & 337 & 37 \\
\hline
\end{tabular}

We can conclude from table 3 that the average frequency of each category represented table 4.

Table 4. The average values of each category

\begin{tabular}{|l|l|}
\hline Low & 3.65 \\
\hline Elevated & 612.3 \\
\hline High & 367.1 \\
\hline Very high & 64.6 \\
\hline Dangerous & 241.4 \\
\hline Poisonous & 16.6 \\
\hline
\end{tabular}

As can be seen from table 4, it can be assumed that the low-level value of atmospheric air pollution appears almost 4 times in 2 years on average. The increased leveled value is 153 times higher on average than the low leveled pollution. The difference between high and dangerous levels is 126 times. Moreover, the poisonous category is less common than all other categories, with the exception of the lowest category. The rarest category is the most needed clean air in the range of 0-12 PM2. 5 is a low category.

\section{Conclusion}

This paper presents a detailed analysis based on Google Colaboratory cloud services to identify the most common categories and the most rarely encountered categories of air pollution indicators. The article [7] considered and identified the top three polluted places according to the installed sensor locations and the top 3 cleanest places analyzed for 2 years. The authors add and propose a categorical grouping for each value of the air pollution level. From six categories presented in the central part of the article, we clearly saw that the low category is infrequent and the most popular types are categories like Elevated where the value range is between 13-34, High between 35-55, and Dangerous 150-249. This means that the Almaty air is contaminated and it is necessary to take measures at the state level and fight for clean air. As the study shows that the largest part of air pollution comes from transport, the authors suggest abandoning passenger cars and switching to public transport. 


\section{References}

1. Internet resource: https://ru.wikipedia.org/wiki/\%D0\%97\%D0\%B0\%D0\%B3\%D1\%80\%D1\%8F\%D 0\%B7\%D0\%BD\%D0\%B5\%D0\%BD\%D0\%B8\%D0\%B5_\%D0\%B0\%D1\%82\%D0\%BC\%D0\%BE\%D1\% 81\%D1\%84\%D0\%B5\%D1\%80\%D1\%8B \%D0\%97\%D0\%B5\%D0\%BC\%D0\%BB\%D0\%B8

2. Koch, T., \& Koch, T. (2005). Cartographies of disease: maps, mapping, and medicine (p. 840). Redlands, CA: Esri Press.

3. Internet resource: https://inbusiness.kz/ru/news/top-3-zagryaznitelej-vozduha-v-kazahstane

4. Duysebekova, K., Serbin, V., Kuandykov, A., Duysebekov, T., Alimanova, M., Orazbekov, S., ... \& Alimzhanova, L. (2016). The Solution of Semi-Empirical Equation of Turbulent Diffusion in Problems of Polluting Impurity Transfer by Gauss Approach. Procedia Computer Science, 94, 372-379.

5. https://www.who.int/ru/news/item/02-05-2018-9-out-of-10-people-worldwide-breathepolluted-air-but-more-countries-are-taking-action

6. Internet resource: https://www.kazpravda.kz/news/obshchestvo/nechem-dishat-v-kakih-gorodahkazahstana-samii-opasnii-vozduh

7. Internet resource: https://www.airkaz.org/pm25.php

8. Internet resource: https://informburo.kz/novosti/zagryaznyonnyy-vozduh-almatypredstavlyaetopasnost-zdorovyu-naseleniya-issledovanie.html

9. Internet resource: https://colab.research.google.com/notebooks/welcome.ipynb?hl=ru

10. Pyagay, V.T., Sarsenova, Z.N., Duisebekova, K.S., Duzbayev, N.T., \& Albanbai, N. (2020). Analysis and processing of environmental monitoring system, Procedia Computer Science, 170, 26-33. 